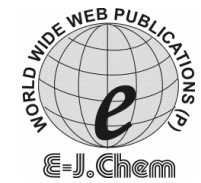

http://www.e-journals.net
ISSN: 0973-4945; CODEN ECJHAO

E-Journal of Chemistry

2008, 5(S1), 980-986.

\title{
Synthesis, Characterization and Evaluation of the Transformations in Hibiscus sabdariffa-graft-poly(butyl acrylate)
}

\author{
B. S. KAITH and AASHISH CHAUHAN* \\ Dr. B. R. Ambedkar National Institute of Technology, \\ (Deemed University), Jalandhar $(\mathrm{Pb})$, India. \\ aashishchauhan16@yahoo.co.in
}

Received 2 March 2008; Accepted 1 May 2008

\begin{abstract}
Different reaction parameters for the graft copolymerization of butyl acrylate onto Hibiscus sabdariffa fiber were optimized. Graft copolymers thus obtained were subjected to characterization using XRD, TGA, DTA, SEM and FTIR techniques and were evaluated for physio-chemical changes in the behavior. The percentage crystallinity and crystallinity index were found to decrease with increase in grafting while there was reduction in moisture absorption and increase in chemical, thermal resistance of the graft copolymers.
\end{abstract}

Keywords: Graft copolymerization, Butyl acrylate and Hibiscus sabdariffa

\section{Introduction}

Natural fibers have been in use since long. In 1886, aeroplane sheets and fuel tanks were made up of natural fibers with small content of polymeric binders. Mixtures of straw and loam were employed as construction composites in Egypt ${ }^{1}$. In other countries people have been using cotton-stark, rice-husk, rice-straw, corn-stark, baggase, cereal-straw and kanaf. India, on the other hand mainly used jute fibers as reinforcement for composites in pipes and panels with polyester matrices ${ }^{2}$. A renaissance in the application of natural fibers as a reinforcing agent has occurred in automobiles and packaging industries in Germany ${ }^{1}$. Natural fibers reinforced composites are used for reinforcing the plastics used for the preparation of door panels and car roofs $^{3}$. Since the natural fibers suffer from various draw-backs such as low weather stability, fast-decaying and low chemical resistance etc. So, the tool in the hands of the chemists for overcoming such draw backs is graft copolymerization that provides the convenient way to 
improve upon its limitations. It modifies the properties of polymer back-bone and incorporates the desired features without drastically affecting the basic traits of the substrate and prepares it for a wide range of applications. In the present paper graft copolymerization of butyl acrylate (BA) onto H. sabdariffa and evaluation of the morphological changes has been reported.

\section{Experimental}

\section{Materials and Method}

Hibiscus sabdariffa was refluxed with acetone for $72 \mathrm{~h}$. Monomers were used as received. Weighing was carried out on Libror AEG-220 (Shimadzu) electronic balance. LEO Electron microscope (S.No.435-25-20) and Perkin Elmer instrument were used for the SEM and IR analysis. $\mathrm{KBr}$ pellets were used for IR-spectrophotometry. X-ray diffraction studies were performed on Bruker- $\mathrm{D}_{8}$ Advance. Thermo gravimetric analysis (TGA) and differential thermal analysis studies (DTA) were conducted in air on thermal analyzer (LINSEIS, L81-11) at a heating rate of $10^{\circ} \mathrm{C} /$ minute.

\section{Graft copolymerization}

Raw Hibiscus sabdariffa fiber $(0.5 \mathrm{~g})$ was activated by swelling in $100 \mathrm{~mL}$ of the distilled water for $24 \mathrm{~h}$. Ceric ammonium nitrate $(\mathrm{CAN})$ and conc. $\mathrm{HNO}_{3}$ were slowly added and stirred, followed by the addition of monomer in specific optimized conditions. Homopolymers thus formed were removed with acetone and alcohol. The graft copolymers were dried at $50^{\circ} \mathrm{C}$, till a constant weight was obtained. The percent grafting $\left(\mathrm{P}_{\mathrm{g}}\right)$ was calculated as reported ${ }^{4,5}$.

$$
\mathrm{P}_{\mathrm{g}}=\frac{\mathrm{W}_{\mathrm{f}}-\mathrm{W}_{\mathrm{i}} \times 100}{\mathrm{~W}_{\mathrm{i}}}
$$

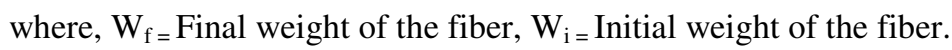

\section{Moisture absorbance and chemical resistance}

Moisture absorbance and the chemical resistance studies were carried out as per the methods reported earlier. ${ }^{5}$ Chemical resistance was calculated by immersing the fiber in strong acidic and alkaline medium for $72 \mathrm{~h}$ followed by drying at $50^{\circ} \mathrm{C}$ till constant weight and calculating the $\%$ weight loss.

\section{Characterization}

$$
\% \text { weight loss }=\mathrm{W}_{\mathrm{i}}-\mathrm{W}_{\mathrm{f}} / \mathrm{W}_{\mathrm{i}} \times 100
$$

\section{FTIR and SEM studies}

In the IR spectrum, of the raw $H$. sabdariffa fiber, a broad peak at $3422 \mathrm{~cm}^{-1}$ due to bonded -OH groups and some additional peaks at $2924.8 \mathrm{~cm}^{-1}, 1454 \mathrm{~cm}^{-1}$ and $1055 \mathrm{~cm}^{-1}$ (arising from $-\mathrm{CH}_{2}$, $\mathrm{C}-\mathrm{C}$ and C-O stretching, respectively) were present. However, in case of $H$. sabdariffag-poly(BA) had a significant peak at $1733 \mathrm{~cm}^{-1}$ (due to $>\mathrm{C}=0$ stretch of acrylate group).

Since the cellulose had non conducting behavior so, they were gold plated to have an impact. The cellulosic fiber lying at a distance in raw sample (Figure 1) started forming bundles in the highest graft copolymers (Figure 2).

\section{$X-R D$ diffraction studies}

$\mathrm{X}$-ray analysis was carried-out using $\mathrm{Cu} \mathrm{K} \alpha\left(1.5418^{\circ} \mathrm{A}\right)$ radiation, Ni-filter and scintillation counter at $40 \mathrm{KV}$ and $40 \mathrm{~mA}$ on rotation between $13^{\circ}$ to $25^{\circ}$ at $2 \theta$ scale at $1 \mathrm{sec}$. step size and increment of 0.01 degree with 0.5 degree or $1.0 \mathrm{~mm}$ of divergent and anti-scattering slit. The continuous scans were taken and different d-spacing $\left({ }^{\circ} \mathrm{A}\right)$ and relative intensity (I) were obtained by tapping small size fiber with glass slide on PMMA holders. 


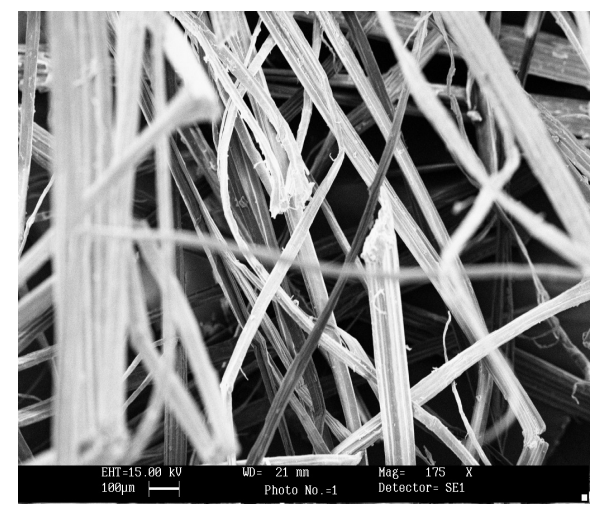

Figure 1. Raw Hibiscus sabdariffa

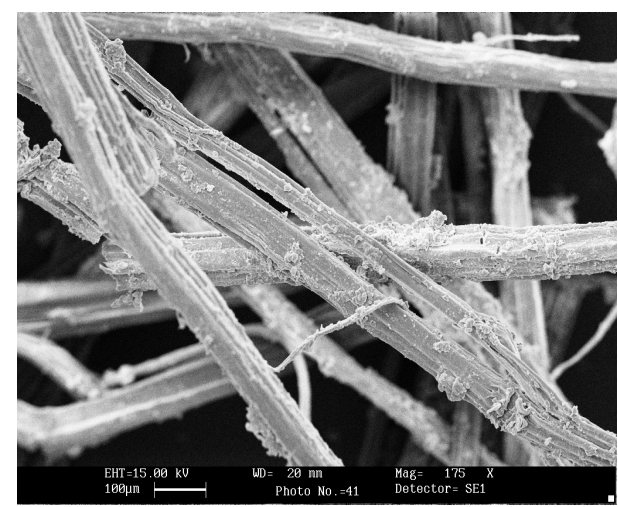

Figure 2. Highest grafted Hs-g-poly(BA)

Thermo gravimetric and differential thermal analysis of graft copolymers

$6.0 \mathrm{mg}$ of the each sample was taken into the silica crucible for TGA / DTA analysis in air with temperature ranging from 50 to $600^{\circ} \mathrm{C}$. The heating rate of the sample was $10^{\circ} \mathrm{C}$ per min and scanned for 60 mins. Air was taken as the reference for zero and the results, delta-M (mg) $v s$. temperature $\left({ }^{\circ} \mathrm{C}\right)$ in case of TGA and DTA signal $(\mu \mathrm{V}) v s$. temperature $\left({ }^{\circ} \mathrm{C}\right)$ in case of DTA, were obtained.

\section{Results and Discussion}

Ceric ions forms the chelate ion with the cellulose molecule through C-2, C-3 hydroxyl groups of the anhydro-glucose unit. Transfer of the electron from the cellulose molecule to Ce(IV) would follow, leading to its reduction to $\mathrm{Ce}(\mathrm{III})$, breakage of $\mathrm{C} 2-\mathrm{C} 3$ bond and the formation of the free radical sites ${ }^{6}$.

Grafting of vinyl monomer onto polymeric backbone could be shown as below:

$$
\begin{aligned}
& \text { Cell-OH }+\mathrm{Ce}^{4+} \longrightarrow \text { Cell-O* }+\mathrm{Ce}^{3+}+\mathrm{H}^{+} \\
& \mathrm{M}+\mathrm{Ce}^{4+} \longrightarrow \mathrm{M}^{*}+\mathrm{Ce}^{3+}+\mathrm{H}^{+}
\end{aligned}
$$

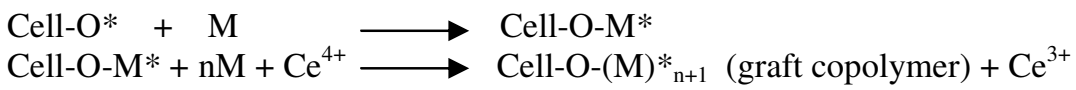

$$
\begin{aligned}
& \mathrm{M}+\mathrm{nM} \longrightarrow(\mathrm{M})^{*}{ }_{n+1} \\
& (\mathrm{M})^{*}{ }_{\mathrm{n}+1}+\mathrm{Ce}^{4+} \longrightarrow(\mathrm{M})^{*}{ }_{\mathrm{n}+1} \text { (homopolymer) }+\mathrm{Ce}^{3+}
\end{aligned}
$$

where, Cell-OH $=H$. sabdariffa backbone (cellulobiose) and $\mathrm{M}=$ butyl acrylate monomer.

\section{Optimization of the reaction parameters}

The parameters like temperature, time, $\mathrm{pH}$, concentration of initiator (CAN), oxidizer $\left(\mathrm{HNO}_{3}\right)$, monomer (butyl acrylate) was optimized in presence of air.

While optimizing the reaction conditions, a range of concentrations were screened but the most favorable conditions were: $35^{\circ} \mathrm{C}$ as reaction temperature with a $\mathrm{Pg}$ of 8.50 (Figure 3a), 120 minutes as the reaction time with a $\mathrm{P}_{\mathrm{g}}$ of 17.60 (Figure $3 \mathrm{~b}$ ), CAN at $2.27 \times 10^{-4} \mathrm{~mole} / \mathrm{L}$ yielded Pg of 40.40 (Figure $3 \mathrm{c}$ ), conc. nitric acid was optimized to be $1.46 \times 10^{-3}$ mole/L that gave the $\mathrm{P}_{\mathrm{g}}$ of $56.75 \%$ (Figure $3 \mathrm{~d}$ ), Butyl acrylate gave the $\mathrm{P}_{\mathrm{g}}$ of 46.05 at $1.40 \times 10^{-3}$ mole/ $\mathrm{L}$ (Figure $3 \mathrm{e}$ ) and the optimization of $\mathrm{pH}$ of the reaction medium at 7.0 approximately resulted in the highest Pg to form $H s$-g-poly(BA) with $66.8 \%$ Pg.(Figure 3f) 

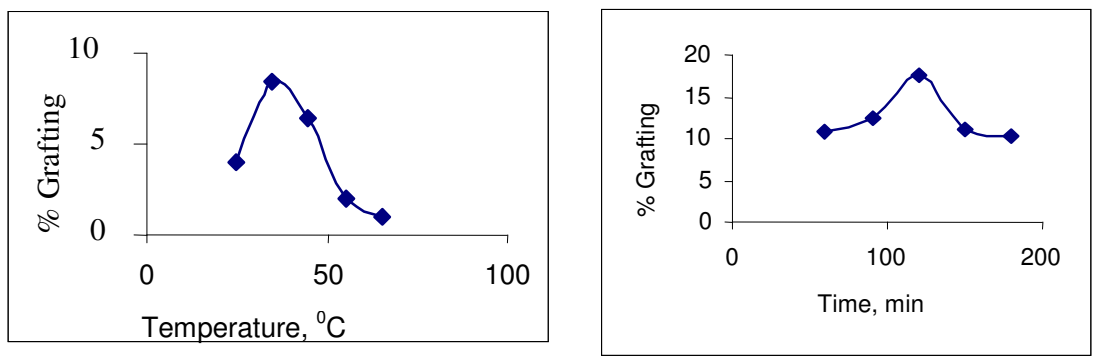

Figure 3a. Effect of temperature on Pg Figure 3b. Effect of time on Pg

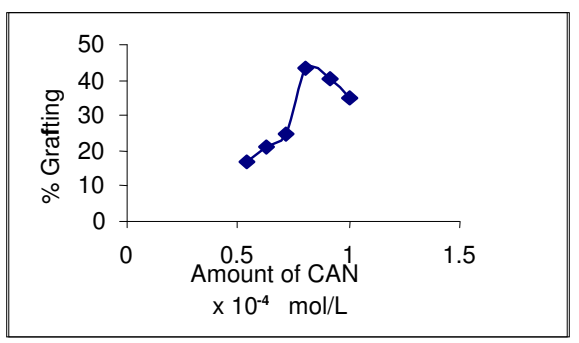

Figure 3c. Effect of initiator amount on $\mathrm{Pg}$
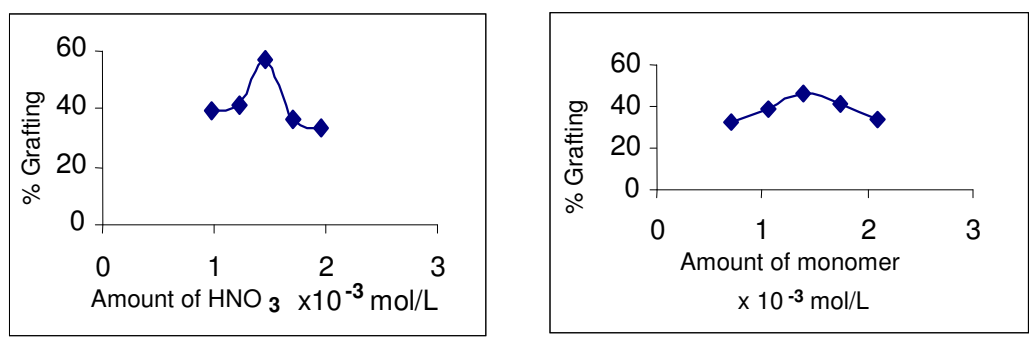

Figure 3d. Effect of Nitric acid Figure 3e. Effect of monomer on Pg amount on $\mathrm{Pg}$

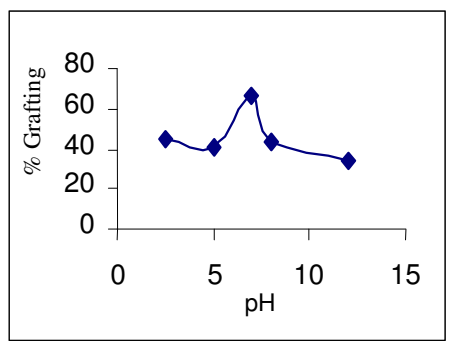

Figure 3f. Effect of $\mathrm{pH}$ on $\mathrm{Pg}$

\section{$X$-ray diffraction studies}

Most of the cellulosic natural fibers possess both crystalline and amorphous regions. The occurrence of both types of features in the fibers indicates that ordered and disordered regions co-exist in crystalline polymers ${ }^{7,8}$. In case of Hibiscus sabdariffa raw fiber, the incorporation 
of additional poly(BA) chains to the back-bone of the polymer disturbed its crystalline lattice and caused a marked loss in crystallinity with increase in the Pg from $71.20 \%$ in raw fiber to $64.19 \%$ in $\mathrm{Hs}$-g-poly(BA). Crystallinity index gives a quantitative measure of the orientation of the cellulose crystals in the fibers. A lower crystalline index in case of graft copolymers means poor order of arrangement of cellulose crystals in the fiber. This is due to misorientation of the cellulose crystals to the fiber axis during grafting in was 0.59 in the raw fiber which decreases to 0.44 in the highest graft copolymer'. Therefore, on grafting crystallinity decreased rapidly with reduction in its stiffness and hardness ${ }^{10}$ resulting in a morphological transformations (Figure 4)

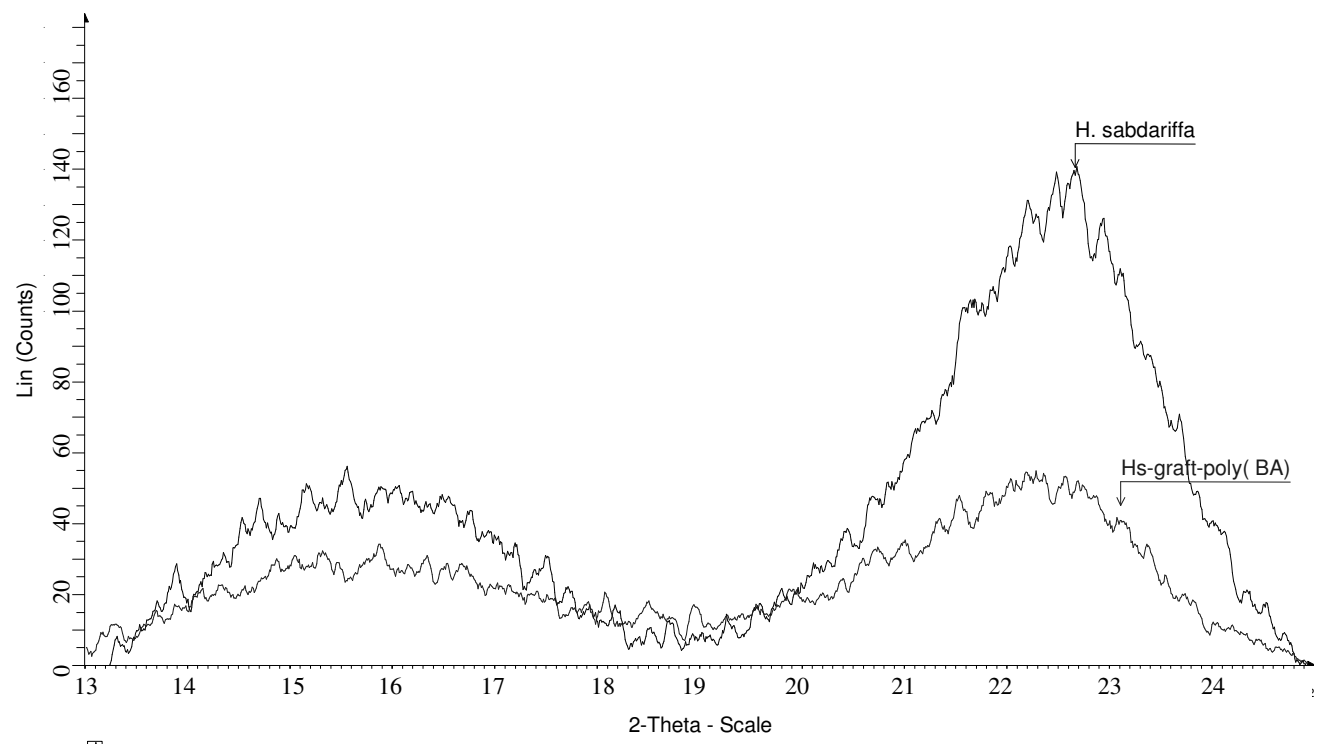

Figure 4. XRPD overlay pattern of Hibiscus sabdariffa and the highest grafted copolymer $H s$-g-poly(BA)

\section{Thermo gravimetric and differential thermal analysis}

Thermo gravimetric analysis of raw $H$. sabdariffa fiber and its graft co-polymers was carried-out as a function of weight loss versus temperature. The results of thermo gravimetric analysis (TGA) has been depicted in Table 1. The degradation occurs in various forms as deacetylation, dehydration, decarboxylation and chain scissions etc. The thermograms of grafted fiber depicts a clear distinctions in two phase decomposition, the first stage signifies the breakdown of cellulose and it shifts to higher temperature as compared to raw fiber while the second stage was related to the degradation of the grafted poly butyl acrylate chain. The shift to higher temperature could be accounted by the increases in the covalent bonds in the graft copolymers varying with the Pg. In case of $H$. sabdariffa fiber, the major weight loss occurs in the first stage due to cellulosic decomposition while the second small peak may be accounted to the oxidation of the $\operatorname{char}^{11}$. In case of raw fiber, both initial decomposition temperature (IDT) and final decomposition temperature (FDT) are lower i.e. $225.7^{\circ} \mathrm{C}$ and $463.0^{\circ} \mathrm{C}$ as compared to those of graft copolymer and therefore results in increased thermal resistance. 
Further, TGA studies had strongly been supported by the DTA evaluation pattern in Table 2. The thermogram of the samples have shown two thermal reaction steps in the temperature range of $314.4-331.6^{\circ} \mathrm{C}$ and $397.3-422.7^{\circ} \mathrm{C}$. The first transition peak revealed the dehydration, adsorption and oxidation from the semi-crystalline host and the second major peak signifies the irreversible dissociation of the crystallites whereas the small peak at $368.1^{\circ} \mathrm{C}$ may be due to fusion. In case of the raw $H$. sabdariffa fiber combustion takes place at lower temperature $\left[314.4^{\circ} \mathrm{C}(18.0 \mu \mathrm{V})\right]$ as compared to graft copolymers which shows that the hydroxyl groups of the native form have been replaced by the covalent bonds.

Table 1. Thermo gravimetric analysis of Hibiscus sabdariffa and its graft co-polymers

\begin{tabular}{cccccccc}
\hline Code & Pg & $\begin{array}{c}\text { Wt. Loss } \\
\text { at } 110^{\circ} \mathrm{C}\end{array}$ & $1^{\text {st }}$ Stg Dec, ${ }^{\circ} \mathrm{C}$. Wt. Loss & $\begin{array}{c}2^{\text {nd }} \\
\text { Dec. }\left({ }^{\circ} \mathrm{C}\right) .\end{array}$ & $\begin{array}{c}\text { Total } \\
\text { wt. loss }\end{array}$ & \% Residue \\
\hline$H s$-raw & 00.00 & 1.12 & $225.7-338.9$ & 3.14 & $338.9-463.0$ & 4.84 & 19.33 \\
$H s$-g-poly(BA) 66.80 & 0.65 & $287.2-349.7$ & 2.73 & $349.7-489.5$ & 5.15 & 14.16 \\
\hline
\end{tabular}

Table 2. Differential thermal analysis of Hibiscus sabdariffa and its graft copolymers

\begin{tabular}{ccc}
\hline Code & $\mathrm{Pg}$ & Observed Peaks ${ }^{\circ} \mathrm{C}[\mu \mathrm{V}]$ \\
\hline$H . s$-raw & 00.00. & $314.4(18.0) ; 422.7(14.0)$ \\
$H s$-g-poly(BA) & 66.80 & $331.6(7.1) ; 368.1(9.2) ; 397.3(22.3)$ \\
\hline
\end{tabular}

\section{Physiochemical evaluation}

The highest grafted copolymers i.e. Hs-g-poly(BA), obtained during optimization of the parameters (as mentioned above) with Pg 8.50, 17.60, 46.05 and 66.80 respectively, were compared to the raw fiber $(\mathrm{Pg}=0)$ for their change in physio-chemical behavior.

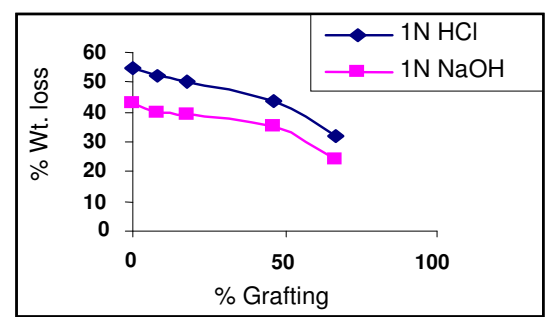

Figure 5. Effect of chemicals on graft copolymers

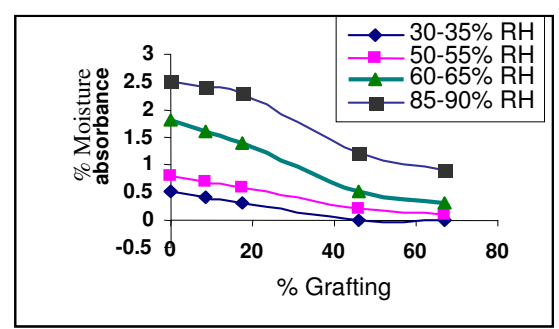

Figure 6. Effect of humidity on graft copolymers

\section{Chemical resistance}

As it is well evident from the Figure 5, that graft co-polymerization imparts resistance to the natural fiber against the alkaline and acidic medium. It has been observed that the increase in the $\mathrm{Pg}$ enhances the chemical resistance. This could be due to the fact that incorporation of hydrophobic moieties through graft copolymerization in natural fiber decreases the chemical sensitivity.

\section{Moisture absorbance}

Similarly, the Figure 6 shows the graft co-polymerization has greatly affected the moisture absorbance behavior of $H$. sabdariffa fiber through incorporation of the hydrophobic organic moieties replacing the free hydroxyl groups at C-2, C-3 and C-6. Thus with increase in Pg there was decrease in the moisture absorbance. 


\section{Conclusion}

Graft co-polymerization is an efficient means to incorporate the desired features into raw fiber while sustaining its required characters. It is evident from the characterization of the graft copolymers through different technique that grafting resulted in the modification of the physico-chemical properties of the $H$. sabdariffa fiber. Moreover, the enhanced moisture, chemical and thermal resistance has been found in these chemically modified fibers.

\section{References}

1. Bledzki A K, Izbicka J and Gussan J, Kunststoffe-Umwelt-Recycling, Stettin Poland, 1995, 27.

2. Pal K, Plast Rubber Process Appl., 1984, 4, 215.

$3 \quad$ Mieck K P and ReBmann T, Kunstsoffe, 1995, 85, 215.

4. Singha A S, Kaith B S and Sanjeev Kumar, Int J Chem Sci., 2004, 2 (3), 472.

$5 \quad$ Kaith B S, Singha A S and Sanjeev Kumar Sharma, J Polym Mater., 2003, 20, 195.

6. Mino G and Kaizerman S, J Polym Sci., 1958, 31, 242.

7. Segal L C, Martin A E and Conrad C M, Tex Res J., 1959, 29, 786-794.

8. Mwaikambo L Y and Ansell M P, J Appl Polym Sci., 2002, 84, 2222-2234.

9. Kaith B S and Susheel Kalia, Int J Polym Anal Charact., 2007, 12, 401-412.

10. Billmeyer F W, Textbook of Polymer Science, 1984, 347.

11. Ouajai S and Shanks R A, Polymer Degradation and Stability, 2005, 89, 327. 


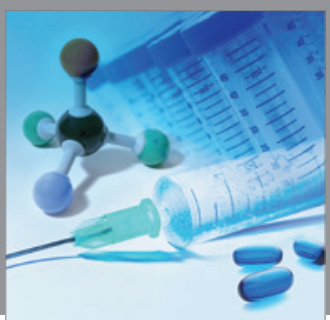

International Journal of

Medicinal Chemistry

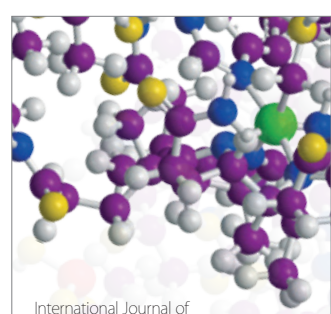

Carbohydrate Chemistry

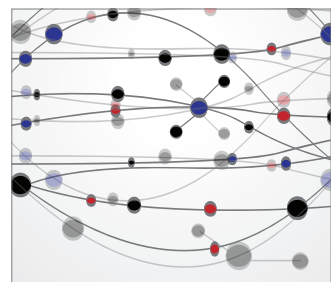

The Scientific World Journal
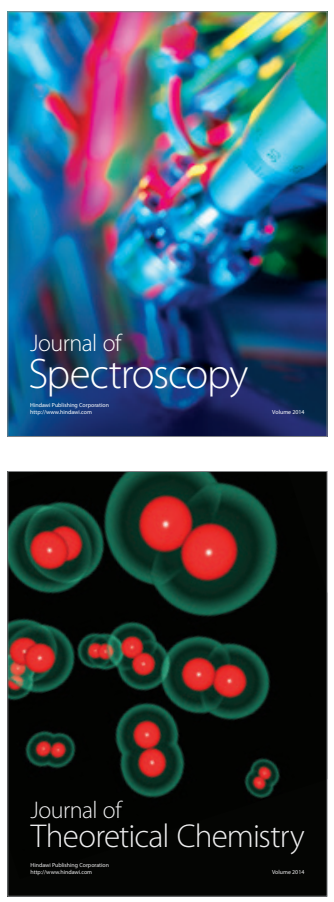
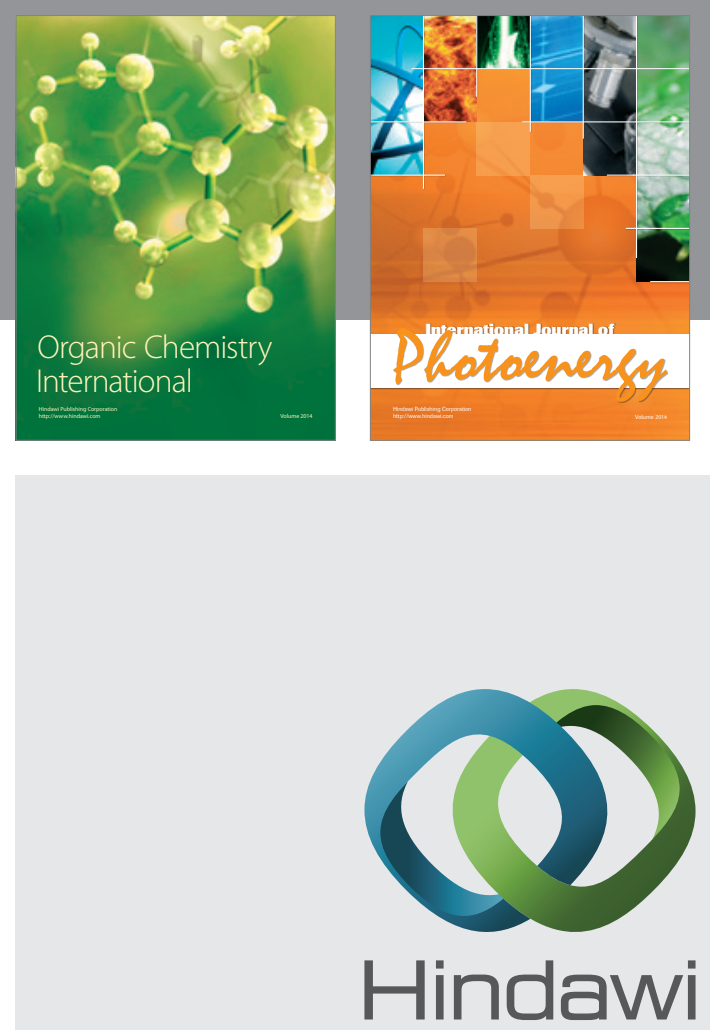

Submit your manuscripts at

http://www.hindawi.com
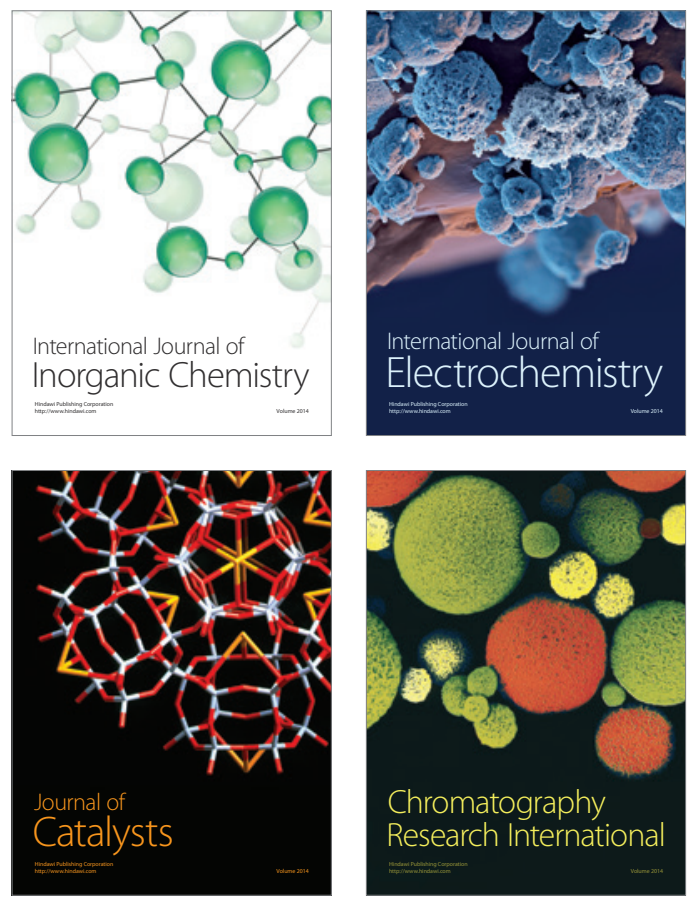
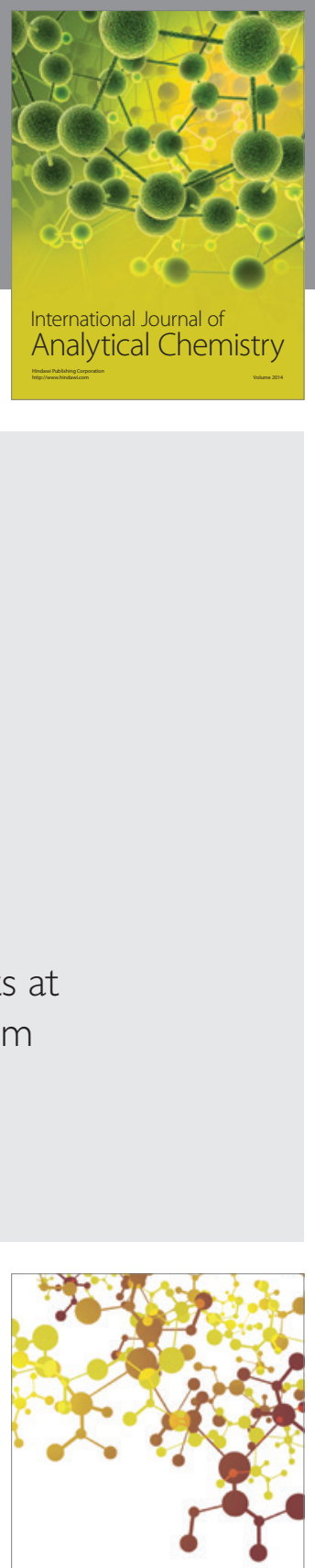

Journal of

Applied Chemistry
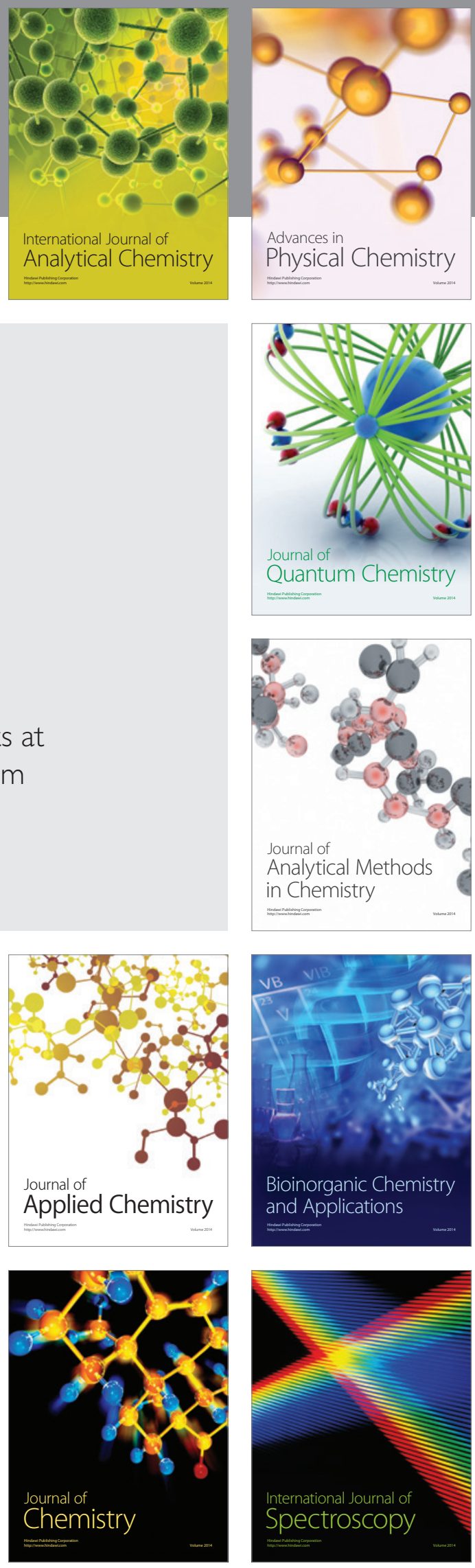